\title{
General View of Malay University Students towards the Image of Turkey
}

\author{
Beytullah Kaya ${ }^{1}$, Ahmed Cagri Inan ${ }^{2, *}$ \\ ${ }^{1}$ Department of History, Humanities and Social Science Faculty, Istanbul Sabahattin Zaim University, Istanbul, Turkey \\ ${ }^{2}$ Department of History and Civilization, International Islamic University Malaysia, Kuala Lumpur, Malaysia
}

Copyright $\odot 2019$ by authors, all rights reserved. Authors agree that this article remains permanently open access under the terms of the Creative Commons Attribution License 4.0 International License

\begin{abstract}
There are some factors affecting people's perceptions towards other countries. Information obtained from textbooks and teachers, especially during a student's primary school education, is arguably amongst the most important factors affecting these perceptions. In addition, media, social media, and family and friendship groups are also among the factors affecting the opinions of students towards other countries [1]. Although few studies have been conducted examining the perceptions and opinions of the international students studying in Turkey, there are fewer studies determining perceptions of other countries' students towards Turkey who are not studying in Turkey (whether in their home country or elsewhere). In this context, the primary aim of this research is to determine Malay university students' perceptions towards with Turkey and its history. In accordance with this purpose, a solution has been created for the identified subproblems in this study. The study is carried out using qualitative research methods. The study is designed as a case study because it is aimed to determine the current situation. Case studies are a preferred method when it is aimed to present the situation in detail. In this context, it aimed to gather data with semi-structured interviews, because it is compatible with the nature of the study. The sample of the study is determined according to the convenience sample method because it is the most easily accessible. In light of the findings obtained from the study, it was understood that information about Ottoman history was included in Malaysian school textbooks and students were aware about the Ottoman Empire. In addition, it was found that some of the students had a positive attitude towards Turkey and up to date information about the country. In order to better comprehend the perception of non-Turkish students towards Turkey, it is advisable that similar studies be carried out in other countries.
\end{abstract}

Keywords Malay Students, Perception towards Turkey, History

\section{Introduction}

Since Turkey has a vast historical, cultural, and religious background, it has a significant political impact in both Europe and the Islamic world. This effect of Turkey provides both advantages and important responsibilities in some cases regarding its relations with neighbouring countries and Islamic countries. It is indisputable that Turkey has emerged as an indispensable partner in the solution of international problems. This situation has been tested once again in recent events in Afghanistan, Iraq and Syria.

In the $9^{\text {th }}$ century, the Turks moved from Central Asia to the West and came towards modern-day Iran and Azerbaijan. Thus, the political and social relations between the Islamic states in the region and the Turks developed. In the $10^{\text {th }}$ century, Karakhanids settled in the Caspian Sea and Idil Bulgarians settled in the Caucasus and both accepted Islam. Hence, a new era has started for both Turks and the Islamic world. Turks began to be influential in the Islamic world in politically and socially, especially at the beginning of the $11^{\text {th }}$ century (1040-1157). The foundation of the Great Seljuk State particularly led the Turks to start playing an active role in the Islamic world in a political, social, and cultural context [2]. The expansion of the lands of the Great Seljuk State into the geography of Asia Minor, the Middle East, and Anatolia while being under the protection of the Abbasid caliphs increased Turkish influence even further [3].

The Great Seljuk State gained political advantage among other Islamic countries due to its protection from the Abbasid Caliphate [4]. With the foundation of the Ottoman Empire, Turks began to spread Islam began to spread towards the Balkans [5]. Since the Ottoman Empire was not only a state dealing with West, she took responsibility to provide peace and tranquillity in the East and Middle Eastern regions [6]. With the expansion of the Ottoman Empire, her lands began to expand on three continents, namely in Africa, Europe and Asia. Hence, Ottoman Empire became responsible for solving problems, which 
arose in these lands.

In other words, the Ottoman Empire tried solve problems not only in their domain, but also in the distant lands. Eventually, the Ottoman Empire began to weaken and to lose her lands. Therefore, the borders of the empire were reduced. In the $19^{\text {th }}$ century, after colonial activities spread in Europe, the countries in which the Muslims lived, began to fall under the control of European states. Some Muslim countries even asked for help from the Ottoman Empire in their struggle with the colonizing powers. The new state founded by the collapse of the Ottoman Empire, whether it wanted to or not, was founded on this historical heritage. This is why Turkey is considered, to this day, a country, which has the ability to provide solutions for the problems in the Muslim world.

The Ottoman Empire played an active role when it was possible to solve the problems in the surrounding regions. In the $16^{\text {th }}$ century, she organized Indian maritime voyages and tried to prevent European states from harassing the areas where Muslims lived [7]. Especially in the periods of Yavuz Sultan Selim and Suleyman the Magnificent, an active policy was followed in this regard. Since the $16^{\text {th }}$ century was the most powerful period of the Ottoman Empire, some problems were solved. By the $19^{\text {th }}$ century, the colonial expansion in the Muslim world thoroughly increased. Despite the weakness of the empire, some Ottoman sultans still concerned with problems in Muslim countries. During the reign of Abdülhamid II, efforts were made to establish relations with close and distant Muslim countries. One of these regions was the Malay Archipelago. In this period, there were different sovereign states in the region and European states increased their colonial activities.

It is not possible to determine precisely when the first relation was established between the Malays and the Turks. However, the first relations between the Malay Archipelago and the Muslims started with commercial activities through a Muslim Turkish dynasty in India [8]. During this period, Turks coming from both Anatolia and Central Asia to the region, were experts in the production of weapons and guns. Turkish sources do not include information on older periods. The Malay sources, however, claim that the relations between the Turks and the Malays were started much earlier on. In addition, even anonymous Malay chronicles claim that these relations based on earlier times and there are kinship ties between the Turks and the Malays [9].

According to these sources, the Malay see themselves as the descendants of Zulkarneyn. In addition, they claim that the Malay ruler, Raca Arustun Shah, married with a princess from Turkestan, hence the Malay ruler and Turkish ruler were of the same lineage $[9,10]$. These and many other similar Malay hikayats provide information on kinship between the Turks and the Malays. In one of these hikayats, the Ottoman Sultan considered one of the greatest sultans in the world and is called as "Raca Rum", and the
Malay sultan claims to be his younger brother [11]. Many European states embarked on colonial activities to exploit the resources of the East with the beginning of natural resources. These colonial activities starting with Spanish and Portuguese then continued with states such as England, France, and the Netherlands and reached its peak during the Industrial Revolution. However, the Ottoman Empire sent aid to the region during the $16^{\text {th }}$ century [12]. In addition, the Ottoman Empire supported the efforts to protect Muslims in Muslim regions.

The Netherlands and Britain shared the Malay Archipelago with the London Treaty of 1824 . In this period, Johor Sultanate was the most important political element of the region. In 1855, Johor Sultanate had to accept British administration [13]. While these developments were taking place, the relations of the Johor Sultanate and the Ottoman Empire started in this period [14]. Abu Bakr, the Sultan of Johor, was hosted many times in the Ottoman palace due to the policy of pan-Islamism, which was implemented during the reign of Abdülhamid II. Sultan Abu Bakr visited Istanbul when he returned from London in 1879. In this visit, Rugayyah Hanum, of Circassian origin, was presented as a gift. After their return to Johor she married to Abdul Majid, the brother of the sultan [15]. During another visit to Istanbul by Sultan Abu Bakr after his pilgrimage, Hatice Hanum presented him as a gift. When the Sultan returned to Johor, his marriage to Hatice Hanum led to the establishment of a kinship bond between the Ottoman Empire and the Johor Sultanate. In this period, the name of the caliph read before the sultans of Johor in the sermons of the mosques. These developments caused improvement of mutual relations between the two states. Children born from Rugayyah Hanum play an active role in the politics and academic world of Malaysia.

The dethroning of Abdülhamid II and Tripoli, Balkan and First World War adversely affected relations between the Ottomans and the Malay. After the defeat in the First World War, the newly established state as a result of the struggle for independence in Anatolia, focused on internal problems. Therefore, there was period of stagnation in political relations between two states until the declaration of independence of Malaysia in 1957. Henceforth, relations between Turkey and Malaysia began to improve again.

Although the relations between Turkey and Malaysia are beginning to improve, the history textbooks in Turkey do not provide any information about Malaysia. In Turkey, students graduate from high school without acquiring any information about Malaysia. On the other hand, in Malaysia, there is information about the Ottoman Empire in history books in the form four grade of secondary school. In history textbooks, the Seljuks and Ottoman Empire are seen as a continuation of the Islamic caliphate [16]. In history textbooks, the Abbasid Caliphate, the Seljuk State and the Ottoman Empire are presented chronologically.

The foundation of the Ottoman Empire, its domination of the other Anatolian principalities, and the struggle with 
the Byzantines are mentioned. Political events that took place with the formation and empowerment of the state are discussed. In the form four grade history book in Malaysia, the Ottoman Empire is seen as an Islamic state and protector of Muslims. History books include information on Ottoman science, legal systems, economy, social structure, and educational concepts [16]. In addition, there is also information on the Ottoman Empire's activities to spread Islam to the Balkans, the Ottoman army's ghazi spirit and the reasons for success of the Ottoman army. The information on development stages of the Ottoman Empire and how it weakened is also included in these books [16].

In this context, when the form four grade history books in Malaysia are evaluated, it is understood that there is an attempt to create positive perception of students towards the Ottoman Empire. In the textbook, there is information about comparison of the Ottoman Empire and the European states, the role of the Ottoman Empire on guidance of the Muslim world, and efforts of the Ottoman Empire to spread Islam. It is expected that the attitudes of the students towards the Ottomans and Turks in general will be positive. Although students learn about Ottoman Empire only in forth form in Malaysia during the entirety of the pre-university education, when the content of the history book is examined, perceptions of students towards the Ottomans and Turks are positive. Meanwhile in Malaysia textbooks do not any information on the Republic of Turkey.

With the rapid development process of Turkey, both citizens of Islamic countries as well as Turkic republics show an interest in Turkey. Thus, the number of international students has seen significant increases in recent years [17]. Although there is an increase in the number of students coming to Turkey there are no academic studies on students' perception towards Turkey, their expectations from Turkey, or what difficulties they faced in Turkey. In addition, there are few studies on Turkey's image in other countries. In this context, this study determines the perception of Malay university students toward Turkey. In this study, the following sub-problems on Malay university students were searched.

1. What is their perception of the Ottoman Empire?

2. How is their perception of the Republic of Turkey?

3. What is their latest information on Turkey?

4. Which information do they have about the relationship between Turkey and Malaysia?

\section{Method}

This study aims to determine Malay university students in Malaysia, and their perception of Turkey. This is a case study and utilizes qualitative research methods. Case studies are used in order to present and describe the existing situation [18]. Qualitative case studies reveal the results of one or more situations $[19,20,21]$. It can also be used to monitor developments and changes that have taken place in the process. Qualitative case studies do not allow generalization due to the fact that it is intended to work with a small number of people and to gather in-depth information. Although there are many different case study methods in literature, descriptive/explanatory case study is used since it is aimed to describe the situation in this research. Especially when the reader does not have sufficient knowledge about the subject, it aims to clarify the subject by using this method and making necessary descriptions and explanations. Qualitative research methods have been preferred in this research because it provides the researcher with the opportunity to reach more extensive data and to collect more in-depth information $[19,20]$. This method has been used because the studies to determine the perceptions of people's minds are more appropriate for the qualitative research method $[21,22,23]$. The data were collected by interview, which was prepared according to semi-structured interview techniques.

\subsection{Sample of the Research}

Twelve students from different departments of the International Islamic University Malaysia participated in this study. The participants were selected according to the appropriate sampling from non-selective sample methods due to their easy accessibility. Only Malay students were selected as participants in this study. One of the most important factors conducting this study at this university is the fact that one of the researchers is educated there and knows the student profile closely.

\subsection{Data Collection and Analysis}

In order to carry out the study, a semi-structured interview form consisting of five questions was prepared. Researchers who specialize in qualitative research methods and study in this field are working at two different universities in Turkey. The interview questions were examined by two field experts to ensure the content validity of the interview form. In line with the opinions of the experts, issues such as covering the subject, being comprehensible, and collecting the necessary data were taken into consideration. As the common opinion of the experts, it was concluded that the interview form was applicable. A pilot study was conducted with a student and the answers of the student were analysed. After the necessary arrangements, it was found that the interview form was applicable. The following questions were included in the interview.

1. What do you know about the Ottoman Empire?

2. What do you know about the Republic of Turkey?

3. What kind of information do you have about Turkey?

4. What do you know about relations between Turkey and Malaysia? 
5. Do you have any information about the establishment of the Republic of Turkey?

Students were interviewed with these questions. During the interview, the probe questions were asked to obtain more information from the students.

Students were given enough information about the purpose of the study. The students all willing volunteered in this research and they were reminded that they had the right to withdraw from the meeting at any time. During the research, guidance for the student participants was avoided. The opinions of students were recorded using a recording device. While content analysis method is used in the analysis of the data, discourse analysis methods are used to present the data. Participants views are put into writing, and the answers given by each student under the title of sub-problems are tabulated as categorical. Student discourses shortened in terms of meaning and content is presented in tables. Data were analysed by the researcher and examined by a field expert. The consensus-based data is determined and those with disagreement is discussed and made available after consensus was reached. In addition, the researcher engaged in conversation, again comparing their responses of students, the consensus has been reached. In this study, the student discourse is given through direct quotation, so the reliability of study is increased.

\section{Findings}

Table 1. Perceptions of Malay university students toward the Ottoman Empire

\begin{tabular}{|c|c|}
\hline S.1. & $\begin{array}{l}\text { In our school books, there is knowledge on the relations between the Ottoman Empire and Melaka Sultanate. I also have } \\
\text { information about the leadership of Sultan Muhammad Al-Fatih. I also know that the Ottoman Empire participated in World War I. }\end{array}$ \\
\hline S.2. & don't know anything about the Ottoman Empire. Maybe we learned some information, but I don't remember. \\
\hline S.3. & $\begin{array}{l}\text { We have some information about the Ottoman Empire under the title of Islamic History in the history textbooks. I also read some } \\
\text { Turkish stories. I don't know anything about the Ottoman Empire during World War I. }\end{array}$ \\
\hline S.4. & $\begin{array}{l}\text { In the Secondary School, Islamic History and Civilization course is taught under four sections. The first one is the period of four } \\
\text { Caliphs, the second is the Umayyad Period, the third is the Abbasid Period and the fourth is the Ottoman Empire. The Ottoman } \\
\text { Empire is called Uthmaniyye. In the English texts, there is a confusion of concept when it is called as the Ottoman Empire. } \\
\text { I have little information about World War I and the allied powers defeated the last Islamic State, the Ottoman State. }\end{array}$ \\
\hline S.5. & We do not have any information in the textbooks. I know World War I, but I don't know about the role of the Ottoman Empire. \\
\hline S.6. & $\begin{array}{l}\text { I know about the foundation of the Ottoman Empire, because there is information about it in our textbooks. World War I began with } \\
\text { the murder of the Polish Prince. Germany attacked Poland. Then Poland and her allies attacked Germany. I have no knowledge of } \\
\text { the Ottomans position in World War I. }\end{array}$ \\
\hline S.7. & $\begin{array}{l}\text { There is a section about the Ottoman in textbooks of secondary school. That's why I have some information. I have some } \\
\text { information about World War I. The Ottomans joined this war. }\end{array}$ \\
\hline S.8. & $\begin{array}{l}\text { My father told me some information about the Ottomans, but I cannot remember now. I have no knowledge of position of the } \\
\text { Ottoman Empire in the World War I. }\end{array}$ \\
\hline S.9. & $\begin{array}{l}\text { In the Form } 4 \text { grade of secondary schools in Malaysia, superficially, the Ottoman Empire period is taught. In addition, Form } 6 \\
\text { courses are taught in detail from the first sultan of the Ottoman Empire to his most recent sultan, Abdülhamid II. I learned about the } \\
\text { Ottoman Empire in these lessons. I don't know much about World War I. }\end{array}$ \\
\hline S.10. & We learned some information in schools, but I can't remember now. I do not know on World War I at all. \\
\hline S.11. & I don't know anything about the Ottomans. \\
\hline S.12. & $\begin{array}{l}\text { I think the Ottoman Empire was the last Islamic Caliphate. I don't remember any Sultan's name. I do not know about the role of } \\
\text { Ottomans in the First World War. }\end{array}$ \\
\hline
\end{tabular}


As it can be seen from the table above which shows perceptions of the Malay university students about the Ottoman Empire, it is understood that most of the students have some information about the Ottoman Empire. In Malaysia, there is a section on Ottoman History in the form four grade textbook. Students who have knowledge about Ottoman History (S1, S3, S4, S8, S9) stated that they have knowledge due to this course. When the history textbook is examined, it is seen that the textbook and student discourses are consistent (Rahman et al., 2017). In this textbook, the content of subject on Ottoman history is given inclusively without going into specific narratives. In accordance with this content, the students consider the Ottoman Empire as a continuation of the Islamic caliphate and recall the Ottoman Empire's aid to the Malacca Sultanate and the relations of the period of Abdülhamid II. It is understood from the table that some students' knowledge about Ottoman history is more accurate in terms of academic and historical consistency.

S1's knowledge about the relations of the period of Malakka Sultanate and the First World War, supports this finding. Moreover, it is found out that S4, S6, S9 and S12 express the Ottoman Empire as a continuation of the Islamic caliphate. This statement corresponds to the information in the textbook. Although S6 states that he has information about the Ottoman Empire, his information about the beginning of the First World War is not historically correct. S1, S4, S7 and S12 claim that they have information about the Ottoman Empire during the First World War. For example, S4 states that the Ottoman Empire joined the First World War and was defeated at the end of the war. S3, S6, S8, S11 and S12 state that they have no information about the First World War. They do not make any statement about the situation of the Ottoman Empire during this war. The discourse of students also corresponds to the textbooks. Because the history books in Malaysia do not contain any information on the Ottoman Empire during the First World War. In the interviews, S11 states that he does not have any information about Ottoman Empire.

When opinions of students are examined, it is seen that all students have the knowledge about Turkey. It is understood that they get this information from the educational environment, friends' groups, or through the media. For students, it is important that Turkey is a Muslim country as Malaysia is. This is understood from the discourse of all students. S1's answers on Turkey geographical location and the relations between Turkey and Europe or NATO shows that student interests in Turkey. Another evidence of interest in Turkey is answers of S2. The students know that Turkey is a Islamic country before and they think that Turkey is a developed country (S1, S3, S4). S12's statement "Turkey has a different alphabet from the Arabic language. However, they like the Arabs as the appearance" shows that student have information about the transformation of Turkey.

Table 2. Perceptions of Malay University Students on Republic of Turkey

\begin{tabular}{|c|c|}
\hline S.1. & $\begin{array}{l}\text { Turkey is a country based between Asia and Europe. Turkey is a member of both the European Union and NATO. It is also a } \\
\text { secular Islamic country. } \\
\text { I learned this information from the books about Turkey, my friends and the internet. }\end{array}$ \\
\hline S.2. & $\begin{array}{l}\text { I know that Turkey has beautiful venues and historical buildings. For example, the Hagia Sophia Mosque. I get information about } \\
\text { Turkey from the internet. }\end{array}$ \\
\hline S3. & I know Turkey as an Islamic country. I get information about Turkey from my friends and TV. \\
\hline S.4. & $\begin{array}{l}\text { Turkey has important roots from the early Islamic period. The most famous city of Turkey is Istanbul. Istanbul is well known part } \\
\text { of Turkey among the Malaysians. We do not have detailed information about Turkey. According to me, Turkey has an important } \\
\text { place in the history of Islam. I learn information about Turkey during secondary school education. }\end{array}$ \\
\hline S.5. & I know that Turkey is a strong country in terms of economic and cultural. I got my information from my friends and the internet. \\
\hline S.6 & Turkey is a country founded after the collapse of the Ottoman Empire. I learn about Turkey from the history lesson and my friends. \\
\hline S.7. & $\begin{array}{l}\text { I know that Turkey is a country in Europe. I know she ruled by the caliph before. Then Ataturk founded the new state. Turkey is one } \\
\text { of my favourite countries, so I am reading about her. }\end{array}$ \\
\hline S.8. & I have information about history and cuisine of Turkey. I'm doing internet research to get information on Turkey. \\
\hline S.9. & $\begin{array}{l}\text { My information about geography of Turkey based on my studies about Byzantine history. My knowledge about Turkey begins with } \\
\text { conquest of Constantinople by Sultan Muhammad al-Fatih, because Muhammad al-Fatih opened the doors of Constantinople with } \\
\text { the Islam army and changed the name of the city to Istanbul. I get information on Turkey from textbooks and my Turkish friends. }\end{array}$ \\
\hline S.10. & $\begin{array}{l}\text { My information on Turkey is limited to what I know about the Ottoman Empire. I get the information from newspapers, magazines } \\
\text { and school lessons. }\end{array}$ \\
\hline S.11. & Turkey is a developed country. I'm watching a documentary on television about Turkey. \\
\hline S.12. & labet from the Arabic language, but they look like Arabs. \\
\hline
\end{tabular}


It is understood from findings that although students do not formally have a knowledge about Turkey, they are interested in cultural, social, academic, and religious issues of Turkey. All students responded to the questions asked under this heading from their perspective and point of interest. For example, statement of S5: "I know Turkey is a strong country in terms of cultural and economic aspect. I get my information from my friends and the Internet", expression of S4: "Turkey has important roots from the early Islamic period. The most famous city of Turkey is Istanbul. Istanbul is well known part of Turkey among the Malaysians. We do not have detailed information about Turkey. According to me, Turkey has an important place in the history of Islam. I learn information about Turkey during secondary school education." and expression of S7: "I know that Turkey is a country in Europe. I know she ruled by the caliph before. Then Ataturk founded the new state. Turkey is one of my favourite countries, so I am reading about her." are examples of this inference.

In this section, students mainly answered questions on the Republic of Turkey. When the students could not give any explanatory information about the Republic of Turkey, the second question was asked about Mustafa Kemal Ataturk. Two of the students (S3 and S11) state that they had learned about Ataturk, but they could not recall information about him. Two students (S2 and S10) state that they do not have any information about Ataturk. The other eight students express a negative opinion about Mustafa Kemal. The students state that they get these opinions from their teachers about Mustafa Kemal. S9 states that "Perhaps, this opinion may not be true from the perspective of the Turks, but we Malaysians, ie, university lecturers, teachers and friends think that Ataturk dissolved an Islamic state and established a non-Islamic state, so we do not evaluate this development as good." S6, S7, S8, S12 also give similar expressions in their opinion. Expression of S4: "Presenting the non-Islamic style of clothing to women" and statement of S5: "...changed azan to Turkish" are the causes of these negative views.

Table 3. The Current Information of Malay University Students on Turkey

\begin{tabular}{|c|c|}
\hline S.1. & $\begin{array}{l}\text { Turkey is a secular country in which Muslim lives. However, secular secularization is declining during Recep Tayyip Erdogan's } \\
\text { government. I can show turkey on the world map. The capital city of Turkey is Ankara. }\end{array}$ \\
\hline S.2. & $\begin{array}{l}\text { Although Turkey is a secular country, there is a respect toward religion. Religion and state affairs are managed separately. I do not } \\
\text { know the location of Turkey on the world map. }\end{array}$ \\
\hline S.3. & I cannot show the location of Turkey on the world map. I do not know who's president of the country right now. \\
\hline S.4. & $\begin{array}{l}\text { I used to think that Turkey strictly linked with Islamic rule. But I think it is like Malaysia as I learn from my Turkish friends. I } \\
\text { follow the relevant interviews about Turkey. I am trying to find the meaning of Turkish words. But Turkish is a complex language. } \\
\text { I know her location on the world map. The current president of Turkey is Erdogan. Turkey's capital is Istanbul. }\end{array}$ \\
\hline S.5. & $\begin{array}{l}\text { According to me, Turkey is an Islamic country. I do not know the location of Turkey on the world map. The current president of } \\
\text { Turkey is Recep Tayyip Erdogan. The capital city of Turkey is Ankara. }\end{array}$ \\
\hline S.6. & $\begin{array}{l}\text { My knowledge on Turkey is limited. Turkey is somewhere in the middle of the East and West on the world map. So, I do not know } \\
\text { exact location where she is. The president of Turkey is Recep Tayyip Erdogan. }\end{array}$ \\
\hline S.7. & $\begin{array}{l}\text { I think Turkey is a secular country, but Recep Tayyip Erdogan is not secular person. Therefore, Islamic teachings began to arrive } \\
\text { again in Turkey. I can show location of Turkey on the world map. Capital city of Turkey is Istanbul. }\end{array}$ \\
\hline S.8. & $\begin{array}{l}\text { I think the Turks are friendly and warm people. I do not know the location of Turkey on the world map. Erdogan is president of } \\
\text { Turkey. I do not know where the capital city of Turkey is. }\end{array}$ \\
\hline S.9. & $\begin{array}{l}\text { The first president, Mustafa Kemal, secularized the country. However, the government gradually turned to an Islamic line with the } \\
\text { Erbakan period. This orientation was not entirely successful. Nowadays, the trend towards an Islamic line continues. But I am not } \\
\text { sure if Turkey is secular or Islamic today, because the current government has interpreted both Islamic and secular ideas in a new } \\
\text { way. I can show the location of Turkey on the world map Turkey. }\end{array}$ \\
\hline S.10. & I do not know about Turkey, her capital city and current president of Turkey. I do not know where location of Turkey is. \\
\hline S.11. & $\begin{array}{l}\text { I know that Turkey is a secular country with Muslim the people. I do not know about Turkey's location, the capital city, and the } \\
\text { current president. }\end{array}$ \\
\hline S.12. & $\begin{array}{l}\text { Turkey is a beautiful country, which is combination of Asian and in European culture. The president of country is Erdogan. Capital } \\
\text { city of Turkey is Ankara and I can show the location of Turkey on the world map. }\end{array}$ \\
\hline
\end{tabular}


From the answers of the students, it is understood that eight of them know the current president of Turkey. Three students state that the capital of Turkey is Ankara. On the other hand, two students claim that Istanbul is the capital of Turkey. Other students do not know where the capital of Turkey is. Eight students, however, express that they can show the location of Turkey on the world map. It is understood that some of the students have advanced information about Turkey. For example, S9 claims "The first president, Mustafa Kemal, secularized the country. However, the government gradually turned to an Islamic line with the Erbakan period. This orientation was not entirely successful. Nowadays, the trend towards an Islamic line continues. But I am not sure if Turkey is secular or Islamic today. Because the current government has interpreted both Islamic and secular ideas in a new way. I can show the location of Turkey on the world map Turkey." This answer shows that students follow current political issues of Turkey. In addition, students describe Turkey as a secular country with the Muslim people. S7 claims "I think Turkey is a secular country, but Recep Tayyip Erdogan is not secular person. Therefore, Islamic teachings began to arrive again in Turkey." This answer indicates that student searches information about Turkey. Moreover, S4 express "I used to think that Turkey strictly linked with Islamic rule. But I think it is like Malaysia as I learn from my Turkish friends. I follow the relevant interviews about Turkey. I am trying to find the meaning of Turkish words. But Turkish is a complex language..." In this answer, the student also claims the source of his opinions on Turkey.

Three students answer the question such as there is no relationship between Turkey and Malaysia, or I do not have any information in this regard. S1 claims "I think our relations are positive from past to present" and he adds that mutual political visits could improve relations. While S6 and S7 answered that they mention that historical background of relations and valuable relations. S6 claims that "...however, there are historical relations. For example, Sultan Selim sent a navy to help during the fall of Malacca." S4 express that "...I do not know much, but I think that inter-university student exchanges are effective in this regard. I also believe that Malay-Ottoman Centre is important to develop for relations. In this way, we can use the methods used by the Ottoman Historians in the study of the Malay history" As can be seen students express their opinion on how relations can be improved. In addition, some students stated that Islamic culture is a common identity, which can improve relations. Answers of students about relations between the two countries are based on cultural and religious coexistence.

Table 4. Opinions of Malay University Students about Relations between Turkey and Malaysia

\begin{tabular}{|c|c|}
\hline S.1. & $\begin{array}{l}\text { I think good relations have been established between previous and current governments of Malaysia and Turkey. I think that our } \\
\text { current Prime Minister will visit to Turkey. I hope that Recep Tayyip Erdogan will come to Malaysia. }\end{array}$ \\
\hline S.2. & I do not think that there is a relationship between Malaysia and Turkey. \\
\hline S.3. & $\begin{array}{l}\text { Turks are very social people. They can easily communicate with other people. I get these opinions during my Turkey visit when I } \\
\text { was in high school. }\end{array}$ \\
\hline S.4. & $\begin{array}{l}\text { I do not know much about this subject, but I think that inter-university student exchanges are effective in this regard. I also believe } \\
\text { that Malay-Ottoman Centre is important to develop relations. In this way, we can use the methods used by Ottoman historians in the } \\
\text { study of Malay history. }\end{array}$ \\
\hline S.5. & I think that we have good relations with Turkey in terms of politic. \\
\hline S.6. & $\begin{array}{l}\text { I cannot say anything globally. There are, however, historical relations. For example, Sultan Selim sent a navy to help during the } \\
\text { fall of Malacca. }\end{array}$ \\
\hline S.7. & $\begin{array}{l}\text { I think we have good relations as two Muslim countries. I think that current relation is based on the relations between the Malacca } \\
\text { Sultanate and the Ottoman Empire. }\end{array}$ \\
\hline S.8. & I have no idea on this subject. \\
\hline S.9. & $\begin{array}{l}\text { We have good relations with Turkey. Turkey is one of the highest civilizations in the Islamic civilization. If Egypt is a role model } \\
\text { for the Muslim world, Turkey is the father of the Muslim world. Turkey's current leader Recep Tayyip Erdogan has a quite } \\
\text { charismatic personality to us. Politically, I do not have much information about the relationship between Malaysia and Turkey. But } \\
\text { we have good relations culturally. That's why I am trying to learn Turkish. }\end{array}$ \\
\hline S. 10 . & I do not know much about this issue. \\
\hline S.11. & I do not know enough about this subject. \\
\hline S.12. & I think we have a common Islamic culture. That's why we have good relations. \\
\hline
\end{tabular}




\section{Conclusions and Discussion}

It is understood from the findings that most Malay university students have information about the Ottoman Empire in accordance with school programs. In addition, they consider the Ottoman Empire as a continuation of the Islamic caliphate. Opinions of students are consistent with the content in their school programs. There are similar contents in the school textbooks of form four [16]. On the other hand, when the literature is examined, it is understood that there are expressions related to relations with both Central Asian Turks and Ottoman Empire in Malay chronicles $[9,11]$. There are no findings on details of these relations in students' expressions. Nevertheless, it was concluded that a considerable portion of the students had knowledge about the Ottoman Empire. The fact that the students consider the Ottoman Empire as a continuation of the Islamic caliphate shows that they have a sense of belonging for the Ottoman Empire.

When we look at the views of students on the Republic of Turkey, it is understood from the research findings that they have knowledge that the Republic of Turkey was founded after the collapse of the Ottoman Empire and the founder of Turkey is Mustafa Kemal. Some of the students had a high level of interest in Turkey and they expressed opinions on cultural and historical treasures of Turkey. It is understood that they have extensive knowledge about Istanbul. Some students claim that Turkey is their favourite country. They state that they get information on Turkey through media, their friends and personal researches. There are some reasons why students are interested in Turkey. For example, Turkey comes from an Islamic culture and Turkey is a modern Muslim country. It is understood from the findings of the study that the students have information about Ataturk.

One of the study results found that students have a negative opinion about some transformations of the new country established by Ataturk and that they negatively evaluate the secular structure of Turkey. One of the most important factors of the high interest of students in Turkey is that Turkey is a modern Muslim country. It was also found, however, that some students are confused about the exact nature of religion and secularism in Turkey, as they will simultaneously claim that it is both religious and secular at the same time. It was determined that students obtain information about Ataturk from their teachers. It is one of the most important results determined by the study that although the absence of any information related to the Republic of Turkey or Ataturk in the textbooks, teachers give negative information about Ataturk to the students.

When the student's current information about Turkey is examined, it is understood that they have information about the location of Turkey. In addition, many students claim that they can show the location of Turkey on the world map. This finding shows that the students have current information on Turkey. Some students express Istanbul as the capital city. Istanbul's historic and cultural background and its fame among world cities lead students to confusion about the capital city of Turkey. Some students express the capital city of Turkey correctly. Some of the Malay students have the information associated with political structure of Turkey. They express their opinion established a secular country by Mustafa Kemal. It is understood from the results of research almost all students know President Recep Tayyip Erdogan and they follow developments in Turkey.

Students closely follow issues on human rights and on the field of Islamic developments in Turkey in recent years. The majority of population is Muslim in Malaysia. In this context, Islamic developments in Turkey are welcomed by Malay students. Recent developments in Turkey are evaluated in this context. Students have a common idea that, historical and cultural relations between Turkey and Malaysia in the past positively affect current relations of two countries. Students, sharing the view that student exchange programs and research centres will contribute to the development of the relations of the two countries, cannot show any exact case for positive relations of Turkey and Malaysia. Thus, it is understood that although students have interest in Turkey in terms of historical, cultural and current issues, they do not have much information about relationships in the political dimension. There are few studies about Turkey's image in other countries. In particular, the lack of such research in other Southeast Asia countries limited this research in terms of comparison of the results.

As a result of this research, it is advised to support and increase this kind of research which can identify people's perceptions for Turkey. In addition, conferences might be organized about Turkey in other countries via Turkish embassies. Moreover, it is thought that student exchange programs and joint research centres can contribute to the development of cultural and social relations between countries and increase the number of studies being conducted.

\section{REFERENCES}

[1] Kaya, B. Friendly and Hostility Perception of 8th Grade Students about Countries. Educational Research and Reviews.10.12. 1766-1772, 2015.

[2] Turan, Ş. Türk Kültür Tarihi (p. 112). İstanbul: Bilgi Yayınevi. 1997

[3] Ocak, A. Selçuklu Devri Üniversiteleri Nizamiye Medreseleri. İstanbul: Nizamiye Akademi. 2017.

[4] Köymen, M.A. Büyük Selçuklu İmparatorluğu Tarihi. 1. Cilt. Ankara: Güven Matbaası. 1979.

[5] Öztürk, N. Oruç Beğ Tarihi (Hazırlayan) İstanbul: Çamlıca. 2008. 
[6] Atik, K. Lütfi Paşa ve Tevarih-i Al-î Osman. Ankara: Başbakanlık Basımevi, 2001.

[7] Milner, A. C. Islam and the Muslim state, Islam in South-East Asia, pp. 23-49, 1983.

https://scholar.google.com/citations?user=m5KpQnIAAAA $\mathrm{J} \& \mathrm{hl}=\mathrm{en} \# \mathrm{~d}=\mathrm{gs}$ md citad $\& \mathrm{p}=\& \mathrm{u}=\% 2 \mathrm{~F}$ citations $\% 3 \mathrm{Fview}$ o p\%3Dview_citation $\% 26 \mathrm{hl} \% 3 \mathrm{Den} \% 26 \mathrm{user} \% 3 \mathrm{Dm} 5 \mathrm{KpQnIA}$ AAAJ\%26citation_for_view\%3Dm5KpQnIAAAAJ\%3Ak IJM86 7U9cC\%26tzom\%3D-180. Access: 20.11.2018.

[8] [8] Bayur, Y.H. Hindistan Tarihi Cilt I. (II. Bask1). Ankara: Türk Tarih Kurumu, 2001.

[9] Leyden, J. Malay Annals. London: A \& R Spottiswoode. 1821

http://sebinaol.unior.it/sebina/repository/catalogazione/doc umenti/Leyden\%20Malay\%20Annals.pdf. Access: 14.11.2018.

[10] Saltık, E. Güney Asya ve Uzak Doğu'da Osmanlı İzleri. İstanbul: Nesil Yay. 2011.

[11] Göksoy, İ. H. "Ottoman-Aceh Relations as documented in Turkish Sources", Mapping the Acehnese Past (eds: R. Michael Feener, Patrick Daly and Anthony Reid), Leiden: KITLV Press, s.65-96, 2011. https://brill.com/view/book/ed coll/9789004253599/B9789004253599-s005.xml. Access: 12.11.2018.

[12] Priatma, D. 16. ve 19. Yüzyıllar Arasında Osmanlı Ve Açe

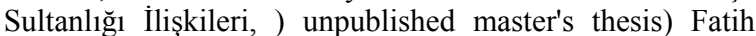
Sultan Mehmet University : İstanbul. 2015.

[13] Yazid, M. N. M. Colonial Policy and the Impact to the Politico-Economy Stability after Independence: The case of Indonesia under the Dutch and Malaysia under the British, Review of History and Political Science, 2.3. pp. 69-84, 2014.

[14] Gürsoy, İ.H. (1999) Malay-Endonezya Kaynaklarına Göre Türkler ve Osmanl1-Açe İlişkileri Tarih İncelemeleri Dergisi. 14.1 .175 - 187,1999. http://www.mulkiyedergi.or g/egetid/article/view/5000135517/5000124376. Access: 11. 11. 2018.

[15] Ozay, M. Islamic Identity \& Development Studies of the Islamic Periphery. Kuala Lumpur: Forum. 1990.

[16] Rahman, N. A., İbrahim, Y., Ahmad, B. \& Sülaiman, R. Sejarah Tingkatan 4. (Ed. Siti Mansi binti Kospin \& Zalehar binti Raub). Kuala Lumpur: Dewan Bahasa dan Pustaka. 2017.

[17] WEB.https://www.ytb.gov.tr/index.php/uluslararasi-ogrenci ler/uluslararasi-ogrenci- hareketliligi. Access: 12.09. 2018.

[18] Yin, K.R. Case study research desing and methods (fourth edition). California: SAGE Publications. 2009.

[19] Karasar, N. Bilimsel Araştırma Yöntemi, Ankara: Nobel Yayın Dağıtım. 2012

[20] Miles, M. B., \& Huberman, A. M. Qualitative data analysis. London: Sage.1994.

[21] Yıldırım, A., Şimşek, H. Sosyal Bilimlerde Nitel Araştırma Yöntemleri. 5. Baskı Ankara: Seçkin. 2005.

[22] Patton, Q. M. Qualitative evaluation and research methods. London: Sage. 2002.
[23] Punch, K. F. (2009). Introduction to research methods in education. London: Sage. 2009. 